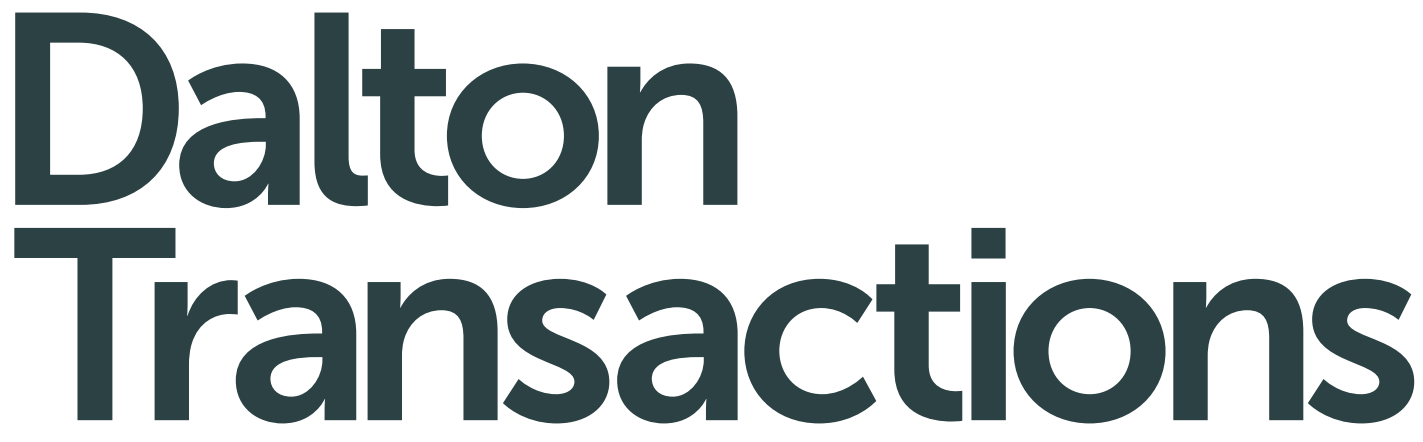

An international journal of inorganic chemistry www.rsc.org/dalton

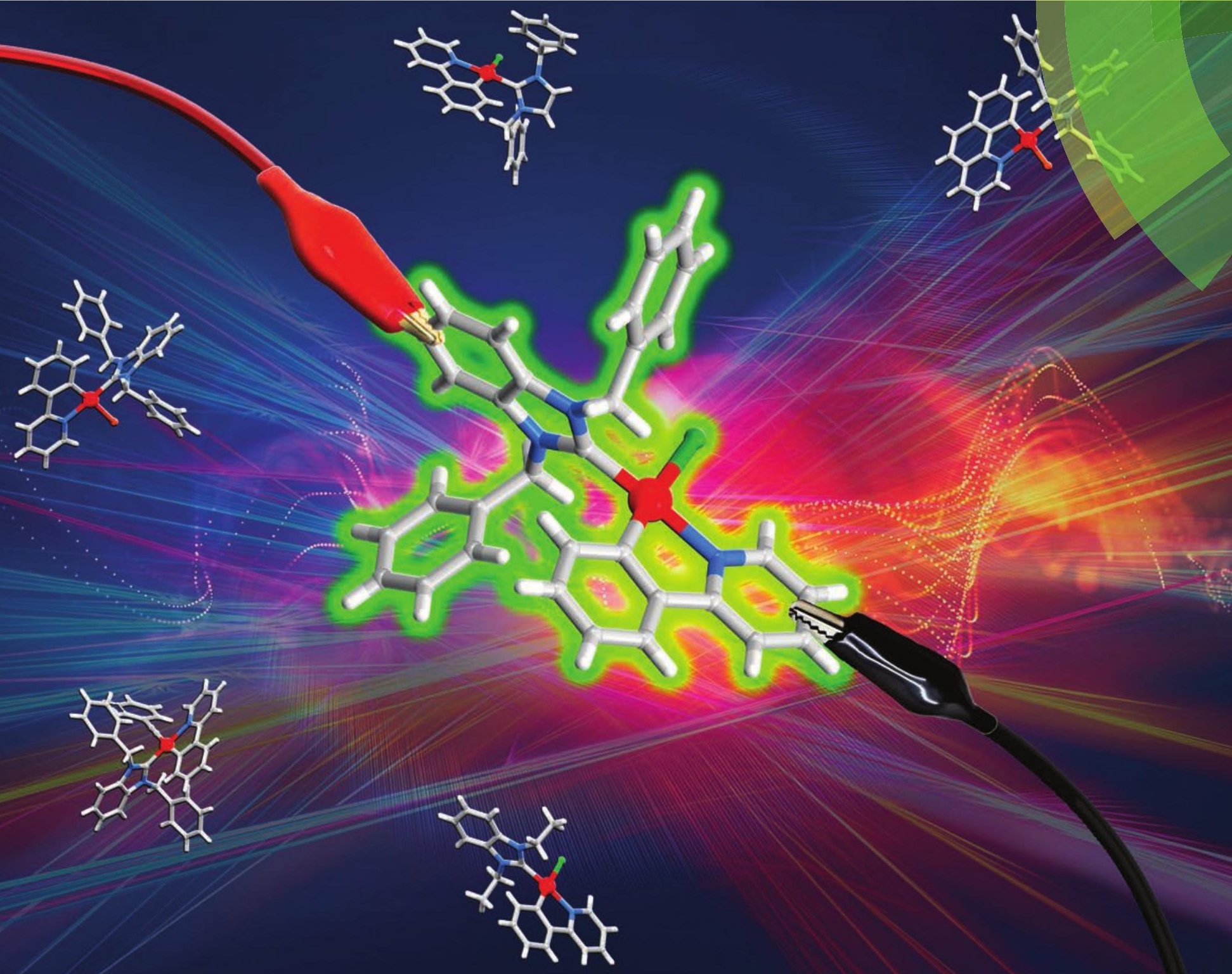

ISSN 1477-9226 


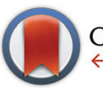

CrossMark \&lick for updates

Cite this: Dalton Trans., 2015, 44 7152

\title{
Cyclometallated platinum(II) complexes containing NHC ligands: synthesis, characterization, photophysics and their application as emitters in OLEDs $\uparrow$
}

\author{
A. I. Solomatina, ${ }^{a}$ D. V. Krupenya, ${ }^{a}$ V. V. Gurzhiy, ${ }^{\text {b }}$ I. Zlatkin, ${ }^{a}$ A. P. Pushkarev, ${ }^{c}$ \\ M. N. Bochkarev, ${ }^{c}$ N. A. Besley, ${ }^{d}$ E. Bichoutskaia ${ }^{d}$ and S. P. Tunik ${ }^{\star^{a}}$
}

\begin{abstract}
A series of square planar $\left[\mathrm{Pt}\left(\mathrm{N}^{\wedge} \mathrm{C}\right)(\mathrm{NHC}) \mathrm{L}\right]$ complexes containing cyclometallated $\mathrm{N}^{\wedge} \mathrm{C}$ ligands (phenylpyridine and benzoquinoline) and $\mathrm{N}$-heterocyclic carbene $(\mathrm{NHC})-\mathrm{N}^{\wedge} \mathrm{C}=2$-phenylpyridine, 7,8-benzoquinoline; $\mathrm{NHC}=1,3$-dibenzylbenzimidazolium, 1,3-diethylbenzimidazolium, 1,3-dibenzylimidazolium; $\mathrm{L}=$ $\mathrm{Cl}, \mathrm{Br},-\mathrm{C}_{2} \mathrm{Ph}-$ have been synthesized in moderate to good yields. The complexes obtained were characterized using chemical analysis, MS-ESI spectrometry, NMR spectroscopy and X-ray crystallography. The complexes display moderate to strong phosphorescence in solution (Q.Y. 0.3-7.9\%) and in the solid state (Q.Y. 2.7-16.0\%), which is related to metal modulated intraligand $\pi-\pi^{\star}$ transitions located at the aromatic system of cyclometallated ligands with some contribution of the MLCT excited state. Emission lifetimes fall in the range of $0.2-1.5 \mu \mathrm{s}$ in solution and amount up to $13 \mu \mathrm{s}$ in the solid state. Analysis of the spectroscopic data together with the density functional theory (DFT) and time-dependent density functional theory (TDDFT) calculations clearly support this assignment and show negligible contribution of the auxiliary ligands to the emissive excited states. The compounds obtained were also used to prepare organic light emitting diode (OLED) devices, which display good luminance efficiency emitting in the green area of the visible spectrum.
\end{abstract}

Received 8th October 2014 Accepted 22nd November 2014

DOI: $10.1039 / \mathrm{c} 4 \mathrm{dt} 03106 \mathrm{~g}$

www.rsc.org/dalton complexes, compounds based on cyclometallated $\mathrm{N}^{\wedge} \mathrm{C}$, $\mathrm{N}^{\wedge} \mathrm{C}^{\wedge} \mathrm{N}, \mathrm{N}^{\wedge} \mathrm{N}^{\wedge} \mathrm{C}$ ligands ${ }^{1-4}$ and those containing $\mathrm{N}$-heterocyclic carbenes $(\mathrm{NHCs})^{5-8}$ are of particular interest. The stability of these complexes in various media and under different conditions, the high yield of triplet emission due to effective intersystem crossing stimulated by the heavy atom effect, easily tunable emission energy controlled by variations in the electronic and steric characteristics of the ligand sphere make these types of $\mathrm{Pt}(\mathrm{II})$ compounds attractive for utilization in the phosphorescence organic light emitting diode (OLED) technology, ${ }^{1,2,9}$ biomedical $^{10-12}$ and sensoric ${ }^{7,13}$ applications. It has been shown, both experimentally and theoretically, that the cyclometallated ligands play a key role in the emission of these complexes. ${ }^{2,3}$ The phosphorescence observed is due to platinum atom modulated intraligand transitions, ${ }^{3} \mathrm{IL}\left(\pi \rightarrow \pi^{*}\right)$, the excited state being centered at the cyclometallated ligand with some admixture of the metal-to-ligand charge transfer, ${ }^{3} \operatorname{MLCT}\left(\mathrm{d}_{\pi}(\mathrm{Pt}) \rightarrow \pi^{*}\right)$. It was also demonstrated that the NHC ligands are not spectators in the emission processes and may modify the phosphorescence quantum yield (QY) considerably, depending on their electronic ${ }^{8}$ and steric $^{6}$ properties. In the present paper we describe the synthesis, characterization and investigation of the photophysical and electroluminescence 
(EL) characteristics of a systematic range of neutral $\left[\mathrm{Pt}\left(\mathrm{N}^{\wedge} \mathrm{C}\right)-\right.$ (NHC)L] complexes, $\mathrm{N}^{\wedge} \mathrm{C}=2$-phenylpyridine, 7,8-benzoquinoline; NHC = 1,3-dibenzylbenzimidazolium, 1,3-diethylbenzimidazolium, 1,3-dibenzylimidazolium; $\mathrm{L}=\mathrm{Cl}, \mathrm{Br},-\mathrm{C}_{2} \mathrm{Ph}$. The electronic structure of the compounds under study is characterized using density functional theory (DFT) calculations, with the time-dependent density functional theory (TDDFT) method used to assign the nature of orbitals responsible for the emission observed. The compounds obtained were used to prepare OLED devices, which displayed a fairly bright green luminescence at low voltage.

\section{Experimental}

Phenylacetylene, 2-phenylpyridine, 7,8-benzoquinoline were commercially available and used without additional purification. Solvents were purified and distilled using standard procedures. The platinum(II) precursor complexes $\left[\mathrm{Pt}\left(\mathrm{N}^{\wedge} \mathrm{C}\right)\right.$ (DMSO)Cl] were prepared according to a published procedure, ${ }^{14}$ and the imidazolium salts were synthesized according to the reported procedures. ${ }^{15-17}$ The Ag(I) complexes with $\mathrm{N}$-heterocyclic carbenes were prepared by the general method. ${ }^{18}$ The solution ${ }^{1} \mathrm{H}$, and $2 \mathrm{D}{ }^{1} \mathrm{H}-{ }^{1} \mathrm{H}$ COSY NMR spectra were recorded on Bruker DPX 300 and Bruker Avance 400 spectrometers, respectively. Mass spectra were recorded on a Bruker micrOTOF 10223 instrument in the $\mathrm{ESI}^{+}$mode (solvent - MeOH). Elemental analyses were carried out with Eurovector Euro-EA3028-HT.

Synthesis of [Pt( $\left.\mathbf{N}^{\wedge} \mathbf{C}-p p y\right)(1,3-d i b e n z y l b e n z i m i d a z o l-2-y l i d e n)-$ Br] (1)

[Pt( $\left.\left.\mathrm{N}^{\wedge} \mathrm{C}-\mathrm{ppy}\right)(\mathrm{DMSO}) \mathrm{Cl}\right](70 \mathrm{mg}, 0.151 \mathrm{mmol})$ and $[\mathrm{Ag}(1,3-$ dibenzylbenzimidazol-2-yliden)Br] (97 $\mathrm{mg}, 0.200 \mathrm{mmol}$ ) were added to $18 \mathrm{ml}$ degassed $\mathrm{CH}_{2} \mathrm{Cl}_{2}$, and the reaction mixture was stirred at room temperature overnight. The gray precipitate was filtered off through Celite and the solvent was removed using a rotary evaporator. The resulting product was added to $10 \mathrm{ml}$ of $\mathrm{KBr}(500 \mathrm{mg}, 4.20 \mathrm{mmol})$ solution in DMSO. The reaction mixture was heated at $100{ }^{\circ} \mathrm{C}$ for $24 \mathrm{~h}$. After cooling to room temperature distilled water was added dropwise to the reaction mixture. The resulting yellow precipitate was filtered off, dried under vacuum and purified by column chromatography on silica using $\mathrm{CH}_{2} \mathrm{Cl}_{2}$ as the eluant. Yield: $71 \mathrm{mg}$ (65\%). Anal. Calcd for $\mathrm{C}_{32} \mathrm{H}_{26} \mathrm{BrN}_{3} \mathrm{Pt}$ : C, 52.83; H, 3.60; N, 5.78. Found: C, 52.77; H, 3.72; N, 5.59\%. ${ }^{1} \mathrm{H}$ NMR (300 MHz, $\mathrm{CDCl}_{3}$, $\left.298 \mathrm{~K}\right)$ : $\delta 9.85$ (d with broad ${ }^{195} \mathrm{Pt}$ satellites, $\left.J_{\mathrm{H}-\mathrm{H}}=5.6 \mathrm{~Hz}, 1 \mathrm{H}\right), 7.86(\mathrm{t}$, $\left.J_{\mathrm{H}-\mathrm{H}}=7.7 \mathrm{~Hz}, 1 \mathrm{H}\right), 7.76\left(\mathrm{~d}, J_{\mathrm{H}-\mathrm{H}}=7.9 \mathrm{~Hz}, 1 \mathrm{H}\right), 7.57\left(\mathrm{~d}, J_{\mathrm{H}-\mathrm{H}}=\right.$ $8.0 \mathrm{~Hz}, 1 \mathrm{H}), 7.53\left(\mathrm{~d}, J_{\mathrm{H}-\mathrm{H}}=6.9 \mathrm{~Hz}, 4 \mathrm{H}\right), 7.26-7.06(\mathrm{~m}, 12 \mathrm{H})$, $6.94\left(\mathrm{t}, J_{\mathrm{H}-\mathrm{H}}=7.4 \mathrm{~Hz}, 1 \mathrm{H}\right), 6.63\left(\mathrm{dd}, J_{\mathrm{H}-\mathrm{H}}=7.6, J_{\mathrm{Pt}-\mathrm{H}}=70 \mathrm{~Hz}\right.$, $1 \mathrm{H}), 6.08\left(\mathrm{dd}, J_{\mathrm{H}-\mathrm{H}}=59.3,15.5 \mathrm{~Hz}, 4 \mathrm{H}\right)$. MS ESI $(\mathrm{m} / \mathrm{z}): 647.18$ $[\mathrm{M}-\mathrm{Br}]^{+}, 749.09[\mathrm{M}+\mathrm{Na}]^{+}, 766.06[\mathrm{M}+\mathrm{K}]^{+}$.

Synthesis of $\left[\mathrm{Pt}\left(\mathrm{N}^{\wedge} \mathrm{C}-\mathrm{ppy}\right)(1,3-\mathrm{dibenzylbenzimidazol-2-yliden})\right.$ Cl] (2)

The compound was prepared according to the procedure described for 1, except that $\mathrm{KCl}(500 \mathrm{mg}, 6.71 \mathrm{mmol})$ was used instead of potassium bromide. Yield: $69 \mathrm{mg}(66 \%)$. Anal. Calcd for $\mathrm{C}_{32} \mathrm{H}_{26} \mathrm{ClN}_{3}$ Pt: C, 56.26; $\mathrm{H}, 3.84 ; \mathrm{N}, 6.15$. Found: C, 55.89; $\mathrm{H}, 4.09 ; \mathrm{N}, 6.31 \% .{ }^{1} \mathrm{H}$ NMR (300 MHz, $\mathrm{CDCl}_{3}, 298 \mathrm{~K}$ ): $\delta 9.66$ (d with broad ${ }^{195} \mathrm{Pt}$ satellites, $\left.J_{\mathrm{H}-\mathrm{H}}=5.1,1 \mathrm{H}\right), 7.87\left(\mathrm{t}, J_{\mathrm{H}-\mathrm{H}}=\right.$ $7.3 \mathrm{~Hz}, 1 \mathrm{H}), 7.76\left(\mathrm{~d}, J_{\mathrm{H}-\mathrm{H}}=7.8 \mathrm{~Hz}, 1 \mathrm{H}\right), 7.67-7.45(\mathrm{~m}, 5 \mathrm{H})$, $7.33-7.05(\mathrm{~m}, 12 \mathrm{H}), 6.94\left(\mathrm{t}, J_{\mathrm{H}-\mathrm{H}}=7.2 \mathrm{~Hz}, 1 \mathrm{H}\right), 6.69\left(\mathrm{dd}, J_{\mathrm{H}-\mathrm{H}}=\right.$ $\left.7.4, J_{\mathrm{Pt}-\mathrm{H}}=70 \mathrm{~Hz}, 1 \mathrm{H}\right), 6.10\left(\mathrm{dd}, J_{\mathrm{H}-\mathrm{H}}=70.5,15.5 \mathrm{~Hz}, 4 \mathrm{H}\right) . \mathrm{MS}$ ESI $(m / z): 647.18[\mathrm{M}-\mathrm{Cl}]^{+}, 706.14[\mathrm{M}+\mathrm{Na}]^{+}, 722.10[\mathrm{M}+\mathrm{K}]^{+}$, $1330.32[2 \mathrm{M}-\mathrm{Cl}]^{+}$.

Synthesis of $\left[\operatorname{Pt}\left(\mathrm{N}^{\wedge} \mathrm{C}\right.\right.$-ppy)(1,3-dibenzylbenzimidazol-2-yliden)$\left.\left(\mathrm{C}_{2} \mathbf{P h}\right)\right](3)$

$35 \mathrm{mg}(0.048 \mathrm{mmol})$ of $1,5 \mathrm{mg}(0.048 \mathrm{mmol})$ phenylacetylene and $1 \mathrm{mg}$ CuI were added to the degassed mixture of $\mathrm{CH}_{2} \mathrm{Cl}_{2}$ $(20 \mathrm{ml}) /$ diisopropylamine $(7 \mathrm{ml})$. The reaction mixture was stirred overnight. The solvent was removed using a rotary evaporator. The product was dissolved in $40 \mathrm{ml}$ dichloromethane and washed with water. The separated organic phase was dried over $\mathrm{Na}_{2} \mathrm{SO}_{4}$. Recrystallization from the dichloromethanehexane mixture gave the product as yellow crystals. Yield: $28 \mathrm{mg}$ (78\%). Anal. Calcd for $\mathrm{C}_{40} \mathrm{H}_{31} \mathrm{~N}_{3} \mathrm{Pt}$ : C, 64.16; H, 4.17; $\mathrm{N}$, 5.61. Found: C, 64.62; H, 4.14; N, 5.31\%. ${ }^{1} \mathrm{H}$ NMR $\left(300 \mathrm{MHz}, \mathrm{CDCl}_{3}, 298 \mathrm{~K}\right): \delta 9.89\left(\mathrm{~d}, J_{\mathrm{H}-\mathrm{H}}=5.2,1 \mathrm{H}\right), 7.85(\mathrm{t}$, $\left.J_{\mathrm{H}-\mathrm{H}}=7.0 \mathrm{~Hz}, 1 \mathrm{H}\right), 7.78\left(\mathrm{~d}, J_{\mathrm{H}-\mathrm{H}}=7.8 \mathrm{~Hz}, 1 \mathrm{H}\right), 7.70-7.58(\mathrm{~m}$, $5 \mathrm{H}), 7.44\left(\mathrm{~d}, J_{\mathrm{H}-\mathrm{H}}=7.4 \mathrm{~Hz}, 2 \mathrm{H}\right), 7.27-7.07(\mathrm{~m}, 15 \mathrm{H}), 7.04(\mathrm{t}$, $\left.J_{\mathrm{H}-\mathrm{H}}=7.3 \mathrm{~Hz}, 1 \mathrm{H}\right), 6.86\left(\mathrm{dd}, J_{\mathrm{H}-\mathrm{H}}=7.2, J_{\mathrm{Pt}-\mathrm{H}}=40 \mathrm{~Hz}, 1 \mathrm{H}\right)$, $6.08\left(\mathrm{dd}, J_{\mathrm{H}-\mathrm{H}}=242.2,15.5 \mathrm{~Hz}, 4 \mathrm{H}\right)$. MS ESI $(\mathrm{m} / \mathrm{z}): 647.18$ $[\mathrm{M}-\mathrm{CCPh}]^{+}, 771.21[\mathrm{M}+\mathrm{Na}]^{+}, 787.18[\mathrm{M}+\mathrm{K}]^{+}$.

\section{Synthesis of $\left[\operatorname{Pt}\left(\mathrm{N}^{\wedge} \mathrm{C}-\mathrm{bzq}\right)(1,3-\right.$ dibenzylbenzimidazol-2-yliden)-} $\mathrm{Br}](4)$

The compound was prepared according to the procedure described for 1 using [Pt $\left.\left(\mathrm{N}^{\wedge} \mathrm{C}-\mathrm{bzq}\right) \mathrm{dmsoCl}\right](74 \mathrm{mg}$, $0.151 \mathrm{mmol}$ ) as the starting material. Yield: $66 \mathrm{mg}(58 \%)$. Anal. Calcd for $\mathrm{C}_{34} \mathrm{H}_{26} \mathrm{BrN}_{3} \mathrm{Pt}$ : C, 54.33; H, 3.49; N, 5.59. Found: C, 54.28; H,3.44; N, 5.46\%. ${ }^{1} \mathrm{H}$ NMR $\left(400 \mathrm{MHz}, \mathrm{CDCl}_{3}\right.$, $298 \mathrm{~K}): \delta 10.04\left(\mathrm{~d}\right.$ with broad ${ }^{195} \mathrm{Pt}$ satellites, $\left.J_{\mathrm{H}-\mathrm{H}}=5.2,1 \mathrm{H}\right)$, $8.35\left(\mathrm{~d}, J_{\mathrm{H}-\mathrm{H}}=8.0 \mathrm{~Hz}, 1 \mathrm{H}\right), 7.80\left(\mathrm{~d}, J_{\mathrm{H}-\mathrm{H}}=8.7 \mathrm{~Hz}, 1 \mathrm{H}\right)$, $7.71-7.60(\mathrm{~m}, 3 \mathrm{H}), 7.55\left(\mathrm{~d}, J_{\mathrm{H}-\mathrm{H}}=6.7 \mathrm{~Hz}, 4 \mathrm{H}\right), 7.32\left(\mathrm{t}, J_{\mathrm{H}-\mathrm{H}}=\right.$ $7.7 \mathrm{~Hz}, 1 \mathrm{H}), 7.28-7.20(\mathrm{~m}, 8 \mathrm{H}), 7.17-7.15(\mathrm{~m}, 2 \mathrm{H}), 6.89(\mathrm{dd}$, $\left.J_{\mathrm{H}-\mathrm{H}}=7.2, J_{\mathrm{Pt}-\mathrm{H}}=70 \mathrm{~Hz}, 1 \mathrm{H}\right), 6.15\left(\mathrm{dd}, J_{\mathrm{H}-\mathrm{H}}=76.3,15.5 \mathrm{~Hz}\right.$, 2H) ppm. MS ESI $(m / z): 671.18[\mathrm{M}-\mathrm{Br}]^{+}$.

\section{Synthesis of $\left[\mathrm{Pt}\left(\mathbf{N}^{\wedge} \mathbf{C}-p p y\right)(1,3-d i e t h y l b e n z i m i d a z o l-2-y l i d e n)-\right.$ Cl] (5)}

The compound was prepared according to the procedure described for 2 using [ $\mathrm{Ag}$ (1,3-diethylbenzimidazol-2-yliden) $\mathrm{Br}$ ] (72 $\mathrm{mg}, 0.200 \mathrm{mmol}$ ) as the starting material. Yield: $47 \mathrm{mg}$ (56\%). Anal. Calcd for $\mathrm{C}_{22} \mathrm{H}_{22} \mathrm{ClN}_{3} \mathrm{Pt}$ : C, 47.27; H, 3.97; N, 7.52. Found: C, $47.39 ; \mathrm{H}, 3.97 ; \mathrm{N}, 7.31 \% .{ }^{1} \mathrm{H}$ NMR $\left(300 \mathrm{MHz}, \mathrm{CDCl}_{3}\right.$, $298 \mathrm{~K}): \delta 9.65$ (d with broad ${ }^{195} \mathrm{Pt}$ satellites, $\left.J_{\mathrm{H}-\mathrm{H}}=5.6,1 \mathrm{H}\right)$, $7.89\left(\mathrm{t}, J_{\mathrm{H}-\mathrm{H}}=7.7 \mathrm{~Hz}, 1 \mathrm{H}\right), 7.78\left(\mathrm{~d}, J_{\mathrm{H}-\mathrm{H}}=8.0 \mathrm{~Hz}, 1 \mathrm{H}\right), 7.58(\mathrm{~d}$, $\left.J_{\mathrm{H}-\mathrm{H}}=7.7 \mathrm{~Hz}, 1 \mathrm{H}\right), 7.54-7.45(\mathrm{~m}, 1 \mathrm{H}), 7.4-7.3(\mathrm{~m}, 3 \mathrm{H}), 7.08(\mathrm{t}$, $\left.J_{\mathrm{H}-\mathrm{H}}=7.5 \mathrm{~Hz}, 1 \mathrm{H}\right), 6.85\left(\mathrm{t}, J_{\mathrm{H}-\mathrm{H}}=7.4 \mathrm{~Hz}, 1 \mathrm{H}\right), 6.39\left(\mathrm{dd}, J_{\mathrm{H}-\mathrm{H}}=\right.$ $\left.7.5, J_{\mathrm{Pt}-\mathrm{H}}=72 \mathrm{~Hz}, 1 \mathrm{H}\right), 4.78\left(\mathrm{q}, J_{\mathrm{H}-\mathrm{H}}=7.2 \mathrm{~Hz}, 4 \mathrm{H}\right), 1.54(\mathrm{t}$, 
$\left.J_{\mathrm{H}-\mathrm{H}}=7.3 \mathrm{~Hz}, 6 \mathrm{H}\right)$ ppm. MS ESI $(\mathrm{m} / \mathrm{z}): 523.15[\mathrm{M}-\mathrm{Cl}]^{+}, 582.10$ $[\mathrm{M}+\mathrm{Na}]^{+}, 1081.26[2 \mathrm{M}-\mathrm{Cl}]^{+}, 1140.21[2 \mathrm{M}+\mathrm{Na}]^{+}$.

\section{Synthesis of [ $\operatorname{Pt}\left(\mathrm{N}^{\wedge} \mathrm{C}-\mathrm{ppy}\right)(1,3-$ dibenzylimidazol-2-yliden $\left.) \mathrm{Cl}\right](6)$}

The compound was prepared according to the procedure described for 2 using [Ag(1,3-dibenzylimidazol-2-yliden)Br] ( $87 \mathrm{mg}, 0.200 \mathrm{mmol}$ ) as the starting material. Yield: $59 \mathrm{mg}$ (62\%). Anal. Calcd for $\mathrm{C}_{28} \mathrm{H}_{24} \mathrm{ClN}_{3} \mathrm{Pt}$ : C, 53.12; H, 3.82; N, 6.64. Found: C, 52.72; H, 3.92; N, 6.29\%. ${ }^{1} \mathrm{H}$ NMR (300 MHz, $\mathrm{CDCl}_{3}$, $298 \mathrm{~K}): \delta 9.66\left(\mathrm{~d}\right.$ with broad ${ }^{195} \mathrm{Pt}$ satellites, $\left.J_{\mathrm{H}-\mathrm{H}}=4.1,1 \mathrm{H}\right)$, $7.87\left(\mathrm{t}, J_{\mathrm{H}-\mathrm{H}}=7.1 \mathrm{~Hz}, 1 \mathrm{H}\right), 7.76\left(\mathrm{~d}, J_{\mathrm{H}-\mathrm{H}}=7.9 \mathrm{~Hz}, 1 \mathrm{H}\right), 7.58(\mathrm{~d}$, $\left.J_{\mathrm{H}-\mathrm{H}}=7.1 \mathrm{~Hz}, 1 \mathrm{H}\right), 7.44\left(\mathrm{~d}, J_{\mathrm{H}-\mathrm{H}}=5.9 \mathrm{~Hz}, 4 \mathrm{H}\right), 7.37-7.29(\mathrm{~m}$, $7 \mathrm{H}), 7.13$ (t, $J=7.3 \mathrm{~Hz}, 1 \mathrm{H}), 6.99$ (t, $J=7.0 \mathrm{~Hz}, 1 \mathrm{H}), 6.80(\mathrm{~s}$, $2 \mathrm{H}), 6.62\left(\mathrm{dd}, J_{\mathrm{H}-\mathrm{H}}=7.3, J_{\mathrm{Pt}-\mathrm{H}}=70 \mathrm{~Hz}, 1 \mathrm{H}\right), 5.69\left(\mathrm{~m}, J_{\mathrm{H}-\mathrm{H}}=\right.$ 62.4, $14.6 \mathrm{~Hz}, 4 \mathrm{H})$ ppm. MS ESI $(\mathrm{m} / \mathrm{z}): 597.16[\mathrm{M}-\mathrm{Cl}]^{+}, 672.10$ $[\mathrm{M}+\mathrm{K}]^{+}, 1230.29[2 \mathrm{M}-\mathrm{Cl}]^{+}$.

\section{Photophysical measurements}

The photophysical measurements in solution were carried out using $\mathrm{CH}_{2} \mathrm{Cl}_{2}$, which was distilled prior to use. All solutions were carefully degassed before lifetime and quantum yield measurements when it was necessary. UV/Vis spectra were recorded on a LAMBDA 1050 spectrophotometer (Perkin Elmer) at a concentration of $3 \times 10^{-5} \mathrm{M}$ (1 cm cuvettes). Emission spectra in solution were recorded on a Fluorolog-3 (JY Horiba Inc.) spectrofluorimeter using a concentration of ca. $3 \times 10^{-5} \mathrm{M}$. The absolute emission quantum yield in solutions was determined by the comparative method using coumarin 102 in ethanol $\left(\Phi_{\mathrm{r}}=0.764\right)^{19}$ as the reference with the refraction indexes of dichloromethane and ethanol equal to 1.42 and 1.36 respectively. The following equation

$$
\Phi_{\mathrm{s}}=\Phi_{\mathrm{r}} \frac{\eta_{\mathrm{s}}^{2} A_{\mathrm{r}} I_{\mathrm{s}}}{\eta_{\mathrm{r}}^{2} A_{\mathrm{s}} I_{\mathrm{r}}}
$$

was used to calculate the quantum yield, where $\Phi_{\mathrm{S}}$ is the quantum yield of the sample, $\Phi_{\mathrm{r}}$ is the quantum yield of the reference, $\eta$ is the refractive index of the solvent, $A_{\mathrm{s}}$ and $A_{\mathrm{r}}$ are the absorbance of the sample and the reference at the wavelength of excitation, respectively, and $I_{\mathrm{S}}$ and $I_{\mathrm{r}}$ are the integrated areas of emission bands. ${ }^{19}$

Microcrystalline samples were used for the photophysical experiments in the solid state. Steady-state photoluminescence spectra were recorded on a Fluorolog-3 spectrofluorimeter. Phosphorescence lifetimes were determined by the TCSPC (Time-Correlated Single Photon Counting) method. The lifetime data were fit using the Jobin-Yvon software package and the Origin 8.1 program. Direct quantum yield measurements of the solid samples in $\mathrm{KBr}$ tablets were performed at room temperature with an integrating sphere from Quanta-phi.

\section{DFT calculations}

The structures of the ground $\left(\mathrm{S}_{0}\right)$ and first excited triplet $\left(\mathrm{T}_{1}\right)$ states of 1-6 were optimized using dispersion corrected density functional theory (DFT-D). The B97-1 exchange-correlation functional ${ }^{20}$ in conjunction with the empirical dis- persion scheme of Grimme ${ }^{21}$ was used with the initial atomic coordinates determined by X-ray crystallography. A basis set comprising the 6-311G(d) basis set for the $\mathrm{C}, \mathrm{H}, \mathrm{N}, \mathrm{Cl}$ atoms and the Stuttgart Relativistic Small Core $^{22,23}$ basis set for Pt and $\mathrm{Br}$ (for brevity this basis set is denoted as SRSC) was used. Vertical excitation energies for the ground state structure were computed using TDDFT calculations at the B97-1/SRSC level in order to evaluate the UV-Vis absorption spectrum. The $\mathrm{S}_{0} \leftarrow$ $\mathrm{T}_{1}$ phosphorescence emission energy was computed using TDDFT, TDDFT with the Tamm-Dancoff approximation ${ }^{24}$ and within the $\Delta$ Kohn-Sham DFT approach. All calculations were performed using the Q-Chem software package. ${ }^{25}$

\section{X-ray analysis}

Crystals suitable for X-ray diffraction analysis were obtained by slow evaporation of dichloromethane from the hexanedichloromethane mixture. Crystal structures of 1-6 were determined by single crystal X-ray diffraction analysis. Crystals were fixed on micro-mounts and the diffraction data were collected on different diffractometers. A crystal of $\mathbf{1}$ was placed on a Bruker Smart Apex II diffractometer and measured at a temperature of $210 \mathrm{~K}$ using monochromated MoK $\alpha$ radiation. Crystals of 2, 5 and 6 were placed on an Agilent Technologies Excalibur Eos diffractometer and measured at a temperature of $100 \mathrm{~K}$ using monochromated MoK $\alpha$ radiation. A crystal of 3 was placed on an Agilent Technologies SuperNova Atlas diffractometer and measured at a temperature of $100 \mathrm{~K}$ using monochromated microfocused $\mathrm{CuK} \alpha$ radiation. A crystal of 4 was placed on an Agilent Technologies SuperNova Atlas diffractometer and measured at a temperature of $100 \mathrm{~K}$ using monochromated microfocused MoK $\alpha$ radiation. The unit cell parameters and refinement characteristics of the crystal structures of 1-6 are given in Table 1 . The structures were solved by direct methods and refined using the SHELXL-97 program $^{26}$ incorporated in the OLEX2 program package. ${ }^{27}$ The carbonbound $\mathrm{H}$ atoms were placed in calculated positions and were included in the refinement in the 'riding' model approximation, with $U_{\text {iso }}(\mathrm{H})$ set to $1.5 U_{\text {eq }}(\mathrm{C})$ and $\mathrm{C}-\mathrm{H} 0.96 \AA$ for the $\mathrm{CH}_{3}$ groups, $U_{\text {iso }}(\mathrm{H})$ set to $1.2 U_{\text {eq }}(\mathrm{C})$ and $\mathrm{C}-\mathrm{H} 0.97 \AA$ for the $\mathrm{CH}_{2}$ groups and $U_{\text {iso }}(\mathrm{H})$ set to $1.2 U_{\text {eq }}(\mathrm{C})$ and $\mathrm{C}-\mathrm{H} 0.93 \AA$ for the $\mathrm{CH}$ groups. Absorption correction for $\mathbf{1}$ was applied using the SADABS program. ${ }^{28}$ Empirical absorption correction for 2-6 was applied in the CrysAlisPro program complex ${ }^{29}$ using spherical harmonics, implemented in the SCALE3 ABSPACK scaling algorithm. Supplementary crystallographic data for this paper have been deposited at Cambridge Crystallographic Data Centre (CCDC 985315, 985316 for 1, 2 and CCDC 985306-985309 for 3-6).

\section{OLED device fabrication and measurements}

The studied devices with the structure ITO/PEDOT:PSS/PVK: complex/BATH/ $/ \mathrm{AlQ}_{3} / \mathrm{Yb}$ consist of poly(3,4-ethylenedioxythiophene)-poly(styrenesulfonate) (PEDOT:PSS) as a hole injection layer, an emissive complex doped into poly(9-vinylcarbazole) (PVK), 4,7-diphenyl-1,10-phenanthroline (BATH) as a holeblocking layer and tris(8-hydroxyquinoline)aluminum $\left(\mathrm{AlQ}_{3}\right)$ as 
Table 1 X-ray crystallographic data of 1-6

\begin{tabular}{|c|c|c|c|c|c|c|}
\hline Compound & 1 & 2 & 3 & 4 & 5 & 6 \\
\hline Formula & $\mathrm{C}_{32} \mathrm{H}_{26} \mathrm{BrN}_{3} \mathrm{Pt}$ & $\mathrm{C}_{32} \mathrm{H}_{26} \mathrm{ClN}_{3} \mathrm{Pt}$ & $\mathrm{C}_{41} \mathrm{H}_{33} \mathrm{Cl}_{2} \mathrm{~N}_{3} \mathrm{Pt}$ & $\mathrm{C}_{34} \mathrm{H}_{26} \mathrm{BrN}_{3} \mathrm{Pt}$ & $\mathrm{C}_{22} \mathrm{H}_{22} \mathrm{ClN}_{3} \mathrm{Pt}$ & $\mathrm{C}_{28} \mathrm{H}_{24} \mathrm{ClN}_{3} \mathrm{Pt}$ \\
\hline Crystal system & Monoclinic & Monoclinic & Monoclinic & Monoclinic & Monoclinic & Monoclinic \\
\hline$b(\AA)$ & $16.8174(11)$ & $16.6139(2)$ & $32.6946(2)$ & $17.1603(4)$ & $10.03648(15)$ & $14.2139(3)$ \\
\hline$c(\AA)$ & $14.9469(10)$ & $14.7861(3)$ & $11.23058(11)$ & $14.9407(4)$ & $18.1023(3)$ & $15.1471(4)$ \\
\hline$\alpha\left({ }^{\circ}\right)$ & 90 & 90 & 90 & 90 & 90 & 90 \\
\hline$\beta\left({ }^{\circ}\right)$ & $106.5640(10)$ & $107.167(3)$ & $112.9906(11)$ & $105.474(3)$ & $103.2305(16)$ & $106.113(2)$ \\
\hline Molecular weight & 727.56 & 683.10 & 833.69 & 751.58 & 558.97 & 633.04 \\
\hline Space group & $P 2_{1} / n$ & $P 2_{1} / n$ & $P 2_{1} / c$ & $P 2_{1} / n$ & $P 2_{1} / n$ & $P 2_{1} / n$ \\
\hline$\mu\left(\mathrm{mm}^{-1}\right)$ & 6.619 & 5.439 & 9.445 & 6.580 & 7.063 & 6.164 \\
\hline Temperature (K) & $210(2)$ & $100(2)$ & $100(2)$ & $100(2)$ & $100(2)$ & $100(2)$ \\
\hline$Z$ & 4 & 4 & 4 & 4 & 2 & 4 \\
\hline$D_{\text {calc }}\left(\mathrm{g} \mathrm{cm}^{-3}\right)$ & 1.767 & 1.717 & 1.632 & 1.814 & 1.831 & 1.806 \\
\hline Angle range $2 \theta\left(^{\circ}\right)$ & $3.74-50.00$ & $5.69-54.99$ & $8.98-153.40$ & $6.08-57.00$ & $5.46-62.00$ & $5.28-55.00$ \\
\hline $\begin{array}{l}\text { Reflections with }\left|F_{\mathrm{o}}\right| \geq \\
4 \sigma_{\mathrm{F}}\end{array}$ & 3505 & 4600 & 6945 & 5774 & 5661 & 4363 \\
\hline$R_{\text {int }}$ & 0.0521 & 0.0417 & 0.0319 & 0.0253 & 0.0322 & 0.0298 \\
\hline$R_{\sigma}$ & 0.0479 & 0.0643 & 0.0151 & 0.0311 & 0.0299 & 0.0435 \\
\hline$R_{1}\left(\left|F_{\mathrm{o}}\right| \geq 4 \sigma_{\mathrm{F}}\right)$ & 0.0328 & 0.0345 & 0.0407 & 0.0380 & 0.0265 & 0.0270 \\
\hline $\mathrm{w} R_{2}\left(\left|F_{\mathrm{o}}\right| \geq 4 \sigma_{\mathrm{F}}\right)$ & 0.0886 & 0.0571 & 0.0910 & 0.1626 & 0.0666 & 0.0532 \\
\hline$R_{1}$ (all data) & 0.0490 & 0.0523 & 0.0417 & 0.0428 & 0.0301 & 0.0408 \\
\hline $\mathrm{w} R_{2}$ (all data) & 0.0932 & 0.0647 & 0.0915 & 0.1682 & 0.0691 & 0.0580 \\
\hline$S$ & 0.956 & 1.051 & 1.104 & 0.976 & 1.064 & 1.065 \\
\hline$\rho_{\min }, \rho_{\max }, \mathrm{e} \AA^{-3}$ & $-1.579,0.635$ & $-1.018,1.537$ & $-2.643,2.164$ & $-1.827,0.890$ & $-1.791,3.032$ & $-0.890,2.014$ \\
\hline
\end{tabular}

an electron-transporting layer. The devices were fabricated by spin-coating and vacuum deposition. A commercial ITO on a glass substrate with $5 \Omega \varepsilon^{-1}$ was used as the anode material (Luminescence Technology Corp.) and a commercial Yb, 99.9\% trace metal basis (Sigma-Aldrich), as the cathode material. ITO glass was sonicated in acetone, isopropanol and deionized water for $10 \mathrm{~min}$ at $60{ }^{\circ} \mathrm{C}$ followed by drying at $120{ }^{\circ} \mathrm{C}$ for $30 \mathrm{~min}$. Substrates were treated in a UV ozone cleaner for $10 \mathrm{~min}$ to improve the working potential of the anode electrode. The PEDOT:PSS layer was spin-coated onto ITO substrates from a $5 \mathrm{wt} \%$ dispersion in water at $4000 \mathrm{rpm}$ for $30 \mathrm{~s}$. The substrates were thereafter annealed at $120{ }^{\circ} \mathrm{C}$ for $10 \mathrm{~min}$ to remove any residual water. Pt(II) complexes (10 wt\%) and the PVK polymer host were dissolved in chloroform. The solutions were spin-cast at $3000 \mathrm{rpm}$ for $30 \mathrm{~s}$ and baked at $80{ }^{\circ} \mathrm{C}$ for $1 \mathrm{~h}$. The substrates were then loaded into the vacuum deposition chamber. The thickness of emissive layers was determined by ellipsometry. BATH, $\mathrm{AlQ}_{3}$, and $\mathrm{Yb}$ were deposited onto the ITO glass by thermal deposition at $1 \times 10^{-6}$ Torr pressure. The deposition rate of the organic compounds and the $\mathrm{Yb}$ complex was $1 \mathrm{~nm} \mathrm{~s}{ }^{-1}$. The thickness of the vacuum deposited layers was determined using a calibrated quartz resonator. The active area of the devices was $5 \times 5 \mathrm{~mm}$. The EL spectra in the visible region and current-luminancevoltage characteristics were measured with an Ocean Optics
USB2000 fluorimeter calibrated with an Ocean Optics LS-1 CAL lamp, the computer controlled GWInstek PPE-3323 power supply and a GW Instek GDM-8246 digital multimeter. The device characteristics were measured under ambient conditions.

\section{Results and discussion}

A series of cyclometallated Pt(II) complexes 1-6 containing NHC ligands was synthesized according to Scheme 1 in moderate to good yields.

The solid state structure of the compounds obtained (1-6) was determined using single crystal X-ray crystallography. Two representative structures are shown in Fig. 1 and 2, and the selected structural parameters are given in figure captions. Structures of the other compounds are shown in Fig. S1 (see $\mathrm{ESI} \dagger)$.

All the complexes display a square-planar geometry with the phenylpyridine and benzoquinoline ligands coordinated in a chelated manner to form five-membered metallocycles. The NHC ligand occupies the trans position with respect to the nitrogen atom of the metallocycle whereas the halide or alkynyl ligands are cis relative to the nitrogen atom of the cyclometallated ligand. All the distances between the platinum 
<smiles>CO[Pb]1(Cl)CCCN1</smiles>

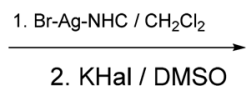<smiles>CN[Te]1([Hg])CCCN1</smiles><smiles>C#CC(C)P</smiles><smiles>CN[P@]1(C#Cc2ccccc2)CCCN1</smiles><smiles>Br[PH]1(c2ccccc2)N(Cc2ccccc2)c2ccccc2N1Cc1ccccc1</smiles><smiles>Cl[PH]1(c2ccccc2)N(c2ccccc2)c2ccccc2N1c1ccccc1</smiles><smiles>C(=CC(c1ccccc1)N1c2ccccc2N(c2ccccc2)c2ccccc21)c1ccccc1</smiles>

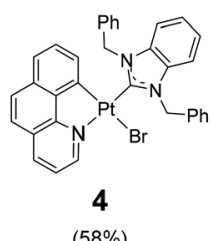<smiles></smiles>

5 $(56 \%)$<smiles>Cl[PH]1(C2C=CC=C2)c2ccccc2-c2ccccc21</smiles>

6

Scheme 1 Synthesis and schematic structure of the complexes 1-6.

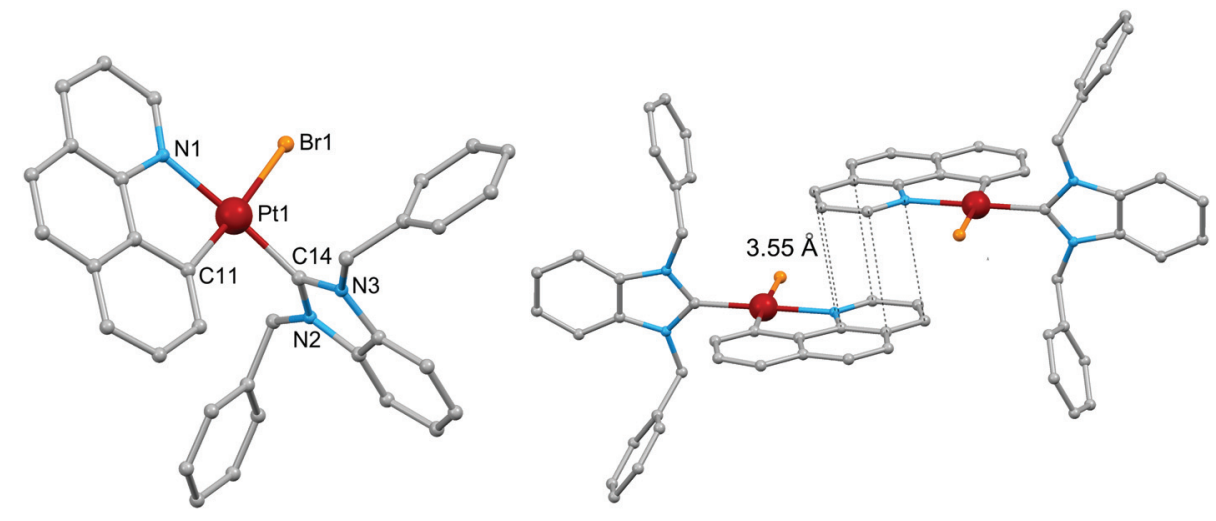

Fig. 1 Solid-state structure of 4. Right part of the figure shows intermolecular contacts in the crystal cell. Selected bond distances ( $\mathrm{A})$ : Pt1-C11 2.027(7), Pt1-C14 1.985(7), Pt1-N1 2.088(5), Pt1-Br1 2.4844(8). Selected angles ('): C11-Pt1-Br1 176.2(2), C14-Pt1-Br1 92.2(2), C11-Pt1-C14 91.5(3), N1-Pt1-Br1 93.1(2), C11-Pt1-N1 83.2(3), C11-Pt1-C12-N3 73.9(6).

center and coordinated atoms fall in the range typical of the compounds of this sort. The angular parameters of the platinum environment also do not display significant deviations from the square-planar geometry. The plane of the five-membered NHC ring is somewhat twisted relative to the platinum centered quadrangle to fit the ring substituents into the crystal cell. It is also to be noted that in contrast to the other compounds studied the benzoquinoline complex $\mathbf{4}$ displays a $\pi$-stacking interaction in the crystal cell to form $\pi$-bound dimers with a typical distance of $c a$. 3.5 A between the stacked aromatic rings, as shown in Fig. 1 . This is evidently determined by the extended aromatic system of the ligand that makes it possible to avoid steric hindrance upon packing of the molecules in the crystal cell. The formation of dimeric aggregates has a considerable impact on the photophysical characteristics of $\mathbf{4}$, vide infra.

In solution, the complexes 1-6 were characterized using $\mathrm{ESI}^{+}$mass spectrometry and ${ }^{1} \mathrm{H}$ NMR spectroscopy. The mass spectra of all complexes (Fig. S11-S17 $\dagger$ ) display positive ions generated either by dissociation of halide (alkynyl) ligands or

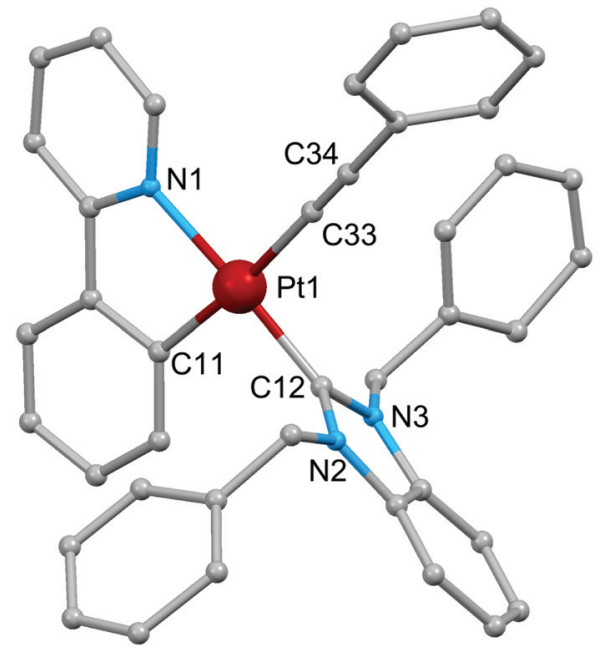

Fig. 2 Solid-state structure of 3 . Selected bond distances (Å): Pt1-C11 2.031(4), Pt1-C12 1.967(4), Pt1-N1 2.078(3), Pt1-C33 2.104(4), C33C34 1.120(5). Selected angles ('): C11-Pt1-C33 174.2(2), C12-Pt1-C33 92.2(2), C11-Pt1-C12 93.2(2), N1-Pt1-C33 94.6(1), C11-Pt1-N1 80.2(1), C11-Pt1-C12-N3 67.4(4). 
by association of the complex molecule with $\mathrm{Na}^{+}\left(\mathrm{K}^{+}\right)$ions. This observation clearly indicates that the stoichiometry found in the solid state is retained in solution. The $1 \mathrm{D}{ }^{1} \mathrm{H}$ and ${ }^{1} \mathrm{H}-{ }^{1} \mathrm{H}$ COSY NMR spectra of 1-6 (Fig. S2-S10†) are completely compatible with the stoichiometry and the square-planar structure of these compounds shown in Fig. 1, 2 and S1. $\dagger$ The number, multiplicity and relative positions of the signals observed (see Experimental and Fig. S2-S10 + ) are consistent with the coordination mode of the ligands revealed in the solid state and the general structural motif of the square-planar complexes.

\section{Photophysical properties}

The complexes studied are luminescent both in solution and in the solid state. Absorption and emission spectra of 1-6 in dichloromethane solution are shown in Fig. 3, and the spectro-

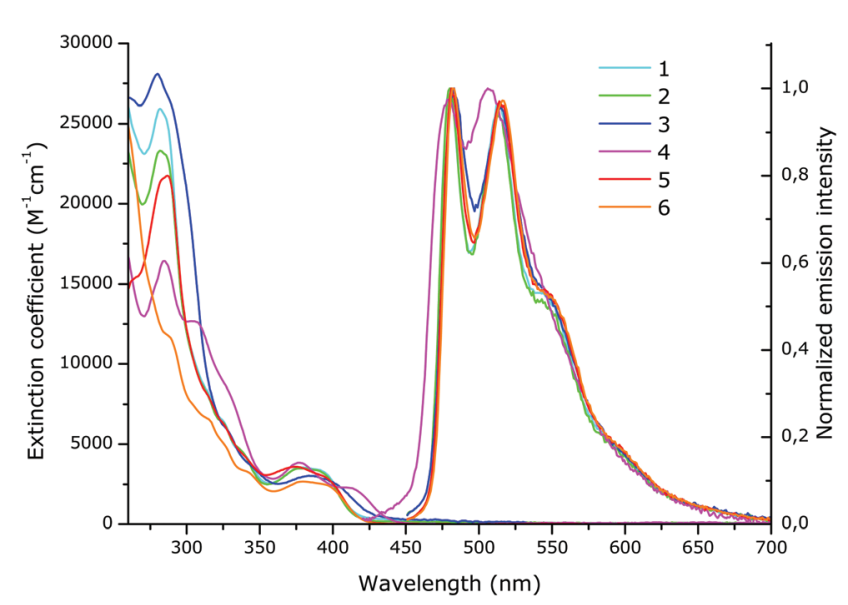

Fig. 3 Room temperature absorption and emission ( $\lambda_{\mathrm{ex}} 385 \mathrm{~nm}$ ) spectra of 1-6 in dichloromethane solution. scopic parameters and photophysical data obtained in solution and in the solid state are summarized in Tables 2 and 3, respectively.

In solution the complexes display strong high energy absorption in the $280-310 \mathrm{~nm}$ range which can be assigned to intraligand electronic transitions whereas weak absorption bands in the $380-410 \mathrm{~nm}$ interval originate from MLCT transitions typical of cyclometallated square-planar Pt(II) complexes. ${ }^{3,4,30}$ Photoexcitation of the complexes 1-6 in a degassed $\mathrm{CH}_{2} \mathrm{Cl}_{2}$ solution gives green emission with the quantum yield ranging from 0.3 to $8 \%$. Large Stokes shift together with the lifetime values in the microsecond domain are indicative of emission origin from the triplet manifold. The triplet nature of the emissive excited state is evidently determined by strong spin-orbit coupling to the central metal atom. The emission bands display clearly resolved vibrational spacing, ca. $1400 \mathrm{~cm}^{-1}$ for 1-3, 5 and 6, whereas the emission band of 4 displays a substantially lower spacing of $1150 \mathrm{~cm}^{-1}$. The former value fits well with the vibrational frequencies of phenylpyridine and clearly points to the strong involvement of the aromatic system into the emissive excited state, whereas the latter might be explained by the difference in vibrational frequencies of the benzoquinoline aromatic systems involved in the emissive transitions. Analogous to the previously studied $\mathrm{Pt}(\mathrm{II})$ complexes $^{3,4,30}$ this emission may be mostly determined by the mixed ${ }^{3} \operatorname{IL}\left(\pi \rightarrow \pi^{*}\right) /{ }^{3} \operatorname{MLCT}\left(\mathrm{d} \pi \rightarrow \pi^{*}\right)$ transitions with a substantial prevalence of the former one. It is also worth noting that the shape of the emission bands as well as the excitation spectra for the complexes containing phenylpyridine (1-3, 5, 6), see Fig. 3, are nearly identical and essentially differ from those for the complex 4 containing the benzoquinoline ligand that indicates once more a primary contribution of the cyclometallated ligands into the IL and

Table 2 Photophysical properties of 1-6 in dichloromethane solution $\left(\lambda_{\mathrm{ex}}=385 \mathrm{~nm}\right)$

\begin{tabular}{|c|c|c|c|c|c|}
\hline & $\lambda_{\mathrm{abs}}(\mathrm{nm})\left(\varepsilon \times 10^{-3}, \mathrm{M}^{-1} \mathrm{~cm}^{-1}\right)$ & $\lambda_{\mathrm{em}}(\mathrm{nm})$ & $\lambda_{\mathrm{ex}}(\mathrm{nm})$ & $\tau_{\mathrm{aer}} / \tau_{\mathrm{deg}}{ }^{a}(\mu \mathrm{s})$ & $\Phi_{\mathrm{aer}} / \Phi_{\mathrm{deg}}{ }^{a}(\%)$ \\
\hline 1 & $282(26), 323 \operatorname{sh}(7), 335 \operatorname{sh}(5), 377$ (4) & $480,515,545 \mathrm{sh}, 590 \mathrm{sh}$ & $335 \mathrm{sh}, 380$ & $0.17 / 1.04$ & $0.6 / 2.3$ \\
\hline 2 & $282(23), 324 \operatorname{sh}(6), 335 \operatorname{sh}(5), 378(3)$ & $480,515,545 \mathrm{sh}, 590 \mathrm{sh}$ & $335 \mathrm{sh}, 380$ & $0.12 / 1.00$ & $1.0 / 5.4$ \\
\hline 3 & $280(28), 325 \operatorname{sh}(6), 343 \operatorname{sh}(4), 384(3)$ & $480,515,545 \mathrm{sh}, 590 \mathrm{sh}$ & 340 sh, 387 & $0.11 / 0.20$ & $0.5 / 1.3$ \\
\hline 4 & $284(16), 305 \operatorname{sh}(13), 323 \operatorname{sh}(9), 377$ (4), 411sh (2) & 478,506 & $304,325 \mathrm{sh}, 399$ & $0.23 / 1.41$ & $<0.1 / 0.3$ \\
\hline 5 & $287(22), 325 \operatorname{sh}(6), 338 \operatorname{sh}(4), 375(4)$ & $480,515,545 \mathrm{sh}, 590 \mathrm{sh}$ & $335 \mathrm{sh}, 385$ & $0.25 / 1.50$ & $1.1 / 7.9$ \\
\hline 6 & $287 \operatorname{sh}(12), 312 \operatorname{sh}(7), 336 \operatorname{sh}(3), 380(3)$ & $480,515,545 \mathrm{sh}, 590 \mathrm{sh}$ & 338sh, 385 & $0.23 / 1.22$ & $1.1 / 7.4$ \\
\hline
\end{tabular}

Table 3 Photophysical data for complexes 1-6 in the solid state

\begin{tabular}{|c|c|c|c|c|}
\hline & $\lambda_{\mathrm{em}}{ }^{a}(\mathrm{~nm})$ & $\lambda_{\mathrm{ex}}{ }^{a}(\mathrm{~nm})$ & $\tau^{a}(\mu \mathrm{s})$ & $\Phi^{b}(\%)$ \\
\hline 1 & $481,505 \mathrm{sh}, 512,540,580 \mathrm{sh}$ & 442,473 & $0.69(55 \%) 2.22(45 \%)$ & 15.8 \\
\hline 2 & $482,505 \mathrm{sh}, 512,540,580 \mathrm{sh}$ & 442,473 & $0.64(45 \%) 2.29(55 \%)$ & 16.0 \\
\hline 3 & $495 \mathrm{sh}, 514,540 \mathrm{sh}, 580 \mathrm{sh}$ & 442,474 & $0.98(42 \%) 4.04(58 \%)$ & 14.2 \\
\hline 4 & $490 \mathrm{sh}, 517,558$ & $408,460 \mathrm{sh}$ & $4.75(31 \%) 13.62(69 \%)$ & \\
\hline 5 & $486,516,545 \mathrm{sh}, 595 \mathrm{sh}$ & 445,475 & $0.34(60 \%) 0.90(40 \%)$ & 2.7 \\
\hline 6 & $479,493,512,540 \mathrm{sh}, 580 \mathrm{sh}$ & 443,477 & $1.33(34 \%) 3.79(66 \%)$ & 9.4 \\
\hline
\end{tabular}

${ }^{a}$ Measurements made using powder samples. ${ }^{b}$ Measurements made using the powder grounded and pressed into the KBr pellet. 
MLCT transitions. Analysis of the data obtained also shows that in degassed solutions the quantum yield of emission as well as the excited state lifetime of the phenylpyridine complexes $(\mathbf{1 - 3}, \mathbf{5}, \mathbf{6})$ display appreciable correlation with the Pt-C (cyclometallated) bond length (see Table S1 and Fig. S17†) that is completely in line with the trend observed earlier ${ }^{31}$ for the photophysics of the structurally related Pt(II) complexes. The lower values of the $\mathrm{Pt}-\mathrm{C}$ bond length (a stronger ligand field effect) result in the higher energy of the $d-d$ excited state, thus cutting off nonradiative relaxation through this excited state. In aerated solutions the emission intensity drops $c a$. an order of magnitude that clearly points to the effective luminescence quenching by molecular oxygen that is typical of triplet emission from the unshielded chromophoric center of the platinum(II) complexes.

In the solid state all but one complex display luminescence with the shape of emission bands essentially similar to those observed in solution (Fig. S21†) which points to similarity of the energy of emissive transitions in both phases. The only exception is complex 4, which shows a slight red shift of emission maximum and a longer/broader band tail in the $600-800 \mathrm{~nm}$ range. This may be ascribed to the $\pi$-stacking of the benzoquinoline ligand that strongly affects specific features of the complex emission compared to the rest of the complexes studied.

It is worth noting that the emissive excited states in the solid state display a double exponential decay (Table 3) that indicates the presence of different conformers in the crystal cell, which have similar energy characteristics but differ in the vibrational relaxation pathways. The excited state lifetimes fall in the microsecond domain that indicates the triplet origin of the emission for all but one (5) complex the lifetime values are substantially higher compared to the values obtained in solution. This observation points to the considerable contribution of vibrational non-radiative deactivation of the triplet excited state in solution, which is suppressed in the solid state by rigid packing of the molecules in the crystal cell as well as by the absence of emission quenching through interactions with solvent molecules.

\section{Computational studies}

The main structural parameters, namely the bond distances and angles around the Pt center, calculated for the $S_{0}$ and $T_{1}$ states of the complexes 1-6 together with the values for the $S_{0}$ state derived from X-ray studies are shown in Table 4 . For the $\mathrm{S}_{0}$ state, there is good agreement between the DFT optimized and X-ray structures. The average deviation between experiment and theory in the bond lengths and bond angles is within $0.03 \AA$ and $1^{\circ}$, respectively. The highest occupied molecular orbital (HOMO) and the lowest unoccupied molecular orbital (LUMO) for the complexes are shown in Fig. 4. This shows that there is no qualitative change in the nature of these orbitals for the different complexes. The HOMO can be described as an out of phase combination of a Pt d orbital with the $\pi$ or $\mathrm{p}$ orbitals associated with $\mathrm{X}$ (where $\mathrm{X}=\mathrm{Cl}, \mathrm{Br}$ or $-\equiv-\mathrm{Ph}$ ) and the $\pi$ orbitals of the ring coordinated opposite to $\mathrm{X}$. The LUMO has little contribution from the Pt atom and can be described as a $\pi^{*}$ orbital that is localized on the phenylpyridine group. In the $\mathrm{T}_{1}$ state these two orbitals are singly occupied, and the corresponding structural parameters for the $T_{1}$ state are also given in Table 4. Comparison of the $\mathrm{S}_{0}$ and $\mathrm{T}_{1}$ structures shows a decrease in the $\mathrm{Pt}-\mathrm{N}, \mathrm{Pt}-\mathrm{C}_{\text {cycl }}$ and $\mathrm{Pt}-\mathrm{X}$ bond lengths on the formation of the $T_{1}$ state, while the majority of the structures show an increase or no change in the $\mathrm{Pt}-\mathrm{C}_{\mathrm{NHC}}$ bond length. The HOMO is clearly antibonding

Table 4 Comparison between DFT optimized structures for the $S_{\circ}$ and $T_{1}$ states and the experimental (X-ray crystallography) structures for the $S_{\circ}$ state. Bond distances in $\AA$ and angles in degrees

\begin{tabular}{|c|c|c|c|c|c|c|c|c|c|}
\hline & X-ray & $\mathrm{S}_{0}$ & $\mathrm{~T}_{1}$ & X-ray & $\mathrm{S}_{0}$ & $\mathrm{~T}_{1}$ & X-ray & $\mathrm{S}_{0}$ & $\mathrm{~T}_{1}$ \\
\hline Pt- $\mathrm{C}_{\mathrm{cycl}}$ & 2.00 & 1.96 & 1.93 & 1.98 & 1.96 & 1.92 & 2.03 & 2.02 & 1.97 \\
\hline $\mathrm{Pt}-\mathrm{C}_{\mathrm{NHC}}$ & 1.95 & 1.92 & 1.94 & 1.96 & 1.96 & 1.94 & 1.97 & 1.92 & 1.94 \\
\hline $\mathrm{Pt}-\mathrm{X}$ & 2.47 & 2.52 & 2.52 & 2.39 & 2.45 & 2.44 & 2.10 & 1.99 & 1.97 \\
\hline $\mathrm{X}-\mathrm{Pt}-\mathrm{C}_{\mathrm{NHC}}$ & 90.4 & 88.9 & 88.1 & 90.6 & 89.6 & 88.5 & 92.2 & 88.3 & 88.3 \\
\hline \multirow[t]{3}{*}{$\mathrm{N}-\mathrm{Pt}-\mathrm{X}$} & 94.1 & 95.8 & 95.3 & 94.0 & 95.1 & 94.7 & 94.6 & 95.7 & 95.1 \\
\hline & \multicolumn{3}{|l|}{4} & \multicolumn{3}{|l|}{5} & \multicolumn{3}{|l|}{6} \\
\hline & X-ray & $\mathrm{S}_{0}$ & $\mathrm{~T}_{1}$ & X-ray & $\mathrm{S}_{0}$ & $\mathrm{~T}_{1}$ & X-ray & $\mathrm{S}_{0}$ & $\mathrm{~T}_{1}$ \\
\hline $\mathrm{C}_{\mathrm{NHC}}-\mathrm{Pt}-\mathrm{C}_{\mathrm{cycl}}$ & 91.5 & 92.9 & 92.8 & 94.2 & 94.5 & 94.7 & 94.4 & 94.5 & 94.4 \\
\hline $\mathrm{C}_{\mathrm{cycl}}-\mathrm{Pt}-\mathrm{N}$ & 83.2 & 82.1 & 83.3 & 81.4 & 81.6 & 83.2 & 80.8 & 81.7 & 83.3 \\
\hline $\mathrm{N}-\mathrm{Pt}-\mathrm{X}$ & 93.1 & 94.9 & 94.3 & 95.1 & 94.8 & 94.3 & 94.7 & 94.7 & 94.1 \\
\hline
\end{tabular}


1

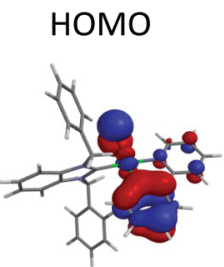

2

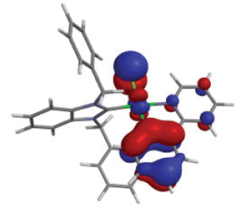

3

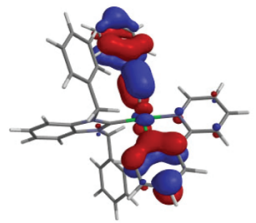

4

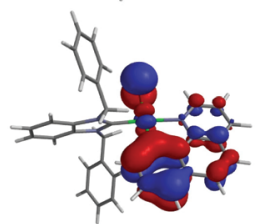

5

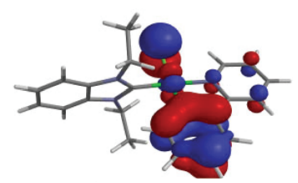

6

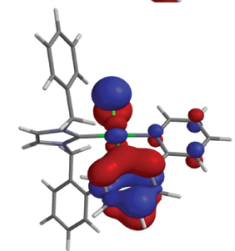

LUMO
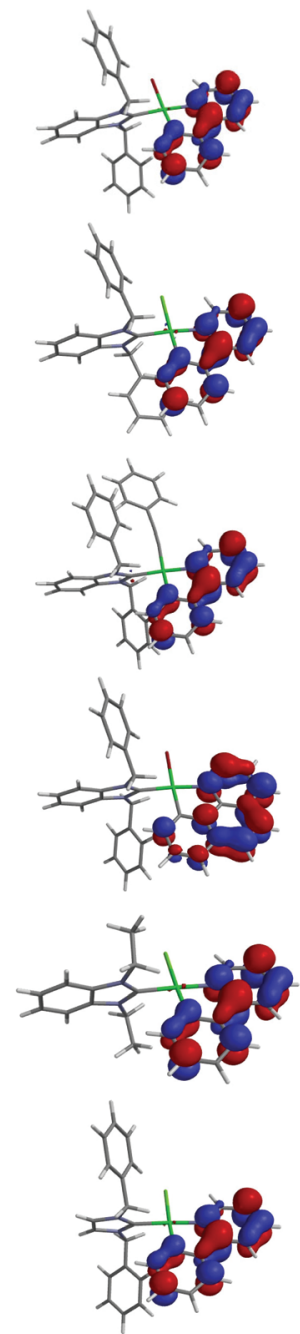

Fig. 4 Kohn-Sham HOMO and LUMO for the $S_{0}$ states of complexes 1-6.

along the Pt-X and $\mathrm{Pt}-\mathrm{C}_{\text {cycl }}$ bonds, which is consistent with the shortening of these bonds on the formation of the $\mathrm{T}_{1}$ state.

Fig. 5 shows the computed TDDFT/SRSC absorption spectrum for complex 5 . The calculations predict bands at 408 and 293 with a shoulder at 275 and $250 \mathrm{~nm}$, which compares bands to that observed in the experiment at 375,325 and $287 \mathrm{~nm}$. This difference between the experiment and the calculations lies within the typical error that is associated with TDDFT calculations particularly considering that the experimental spectrum is measured in $\mathrm{CH}_{2} \mathrm{Cl}_{2}$ while the calculations correspond to the gas phase. This indicates that the hybrid functional B97-1 provides an adequate description of these transitions. The lowest energy band at about $400 \mathrm{~nm}$ arises from excitation from the HOMO, which is a mixture of Pt d and ligand $\mathrm{p}$ and $\pi$ orbitals, to the LUMO which is a ligand $\pi^{*}$ orbital. Consequently this transition can be described as a mixture of MLCT $\mathrm{d} \rightarrow \pi^{*}$ and intraligand $\pi \rightarrow \pi^{*}$ character. The band at $300 \mathrm{~nm}$ arises predominantly from excitation from two

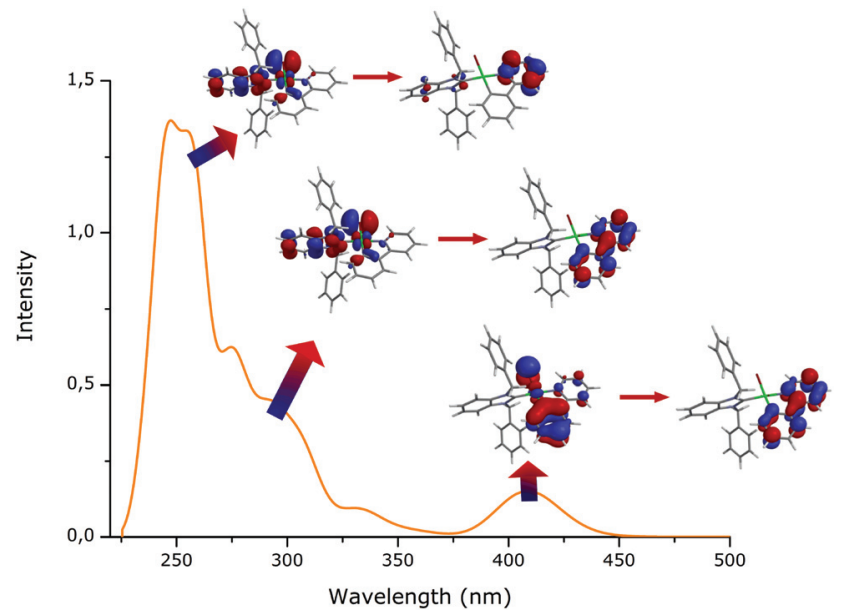

Fig. 5 Computed TDDFT/SRSC absorption spectrum with orbitals illustrating the major transitions for complex 5 .

occupied orbitals of lower energy than the LUMO. These orbitals are largely comprised of ligand $\pi$ orbitals, although there remains a small contribution from the Pt d orbitals.

Similarly, the most intense band corresponds to an excitation of $\pi$ to $\pi^{*}$ orbitals associated with the ligands. As such, these findings are consistent with the description of the broad feature at $225-325 \mathrm{~nm}$ as arising from intraligand $\pi \rightarrow \pi^{*}$ transitions in previous studies, although we note that there remains a small component of the MLCT character in these transitions. Computed spectra for all six complexes are shown in Fig. 6 with the band positions given in Table 5. For all of the complexes, a weaker band is predicted at approximately $400 \mathrm{~nm}$ with broad features between 225 and $350 \mathrm{~nm}$.

The experimental emission spectra for all compounds except $\mathbf{4}$ are very similar and show a broadband with peaks at 485 and $515 \mathrm{~nm}$. The spectrum for 4 has a similar shape but is shifted to a lower wavelength. Table 5 gives the computed $\mathrm{S}_{0} \leftarrow$ $\mathrm{T}_{1}$ transition energies using various DFT based approaches.

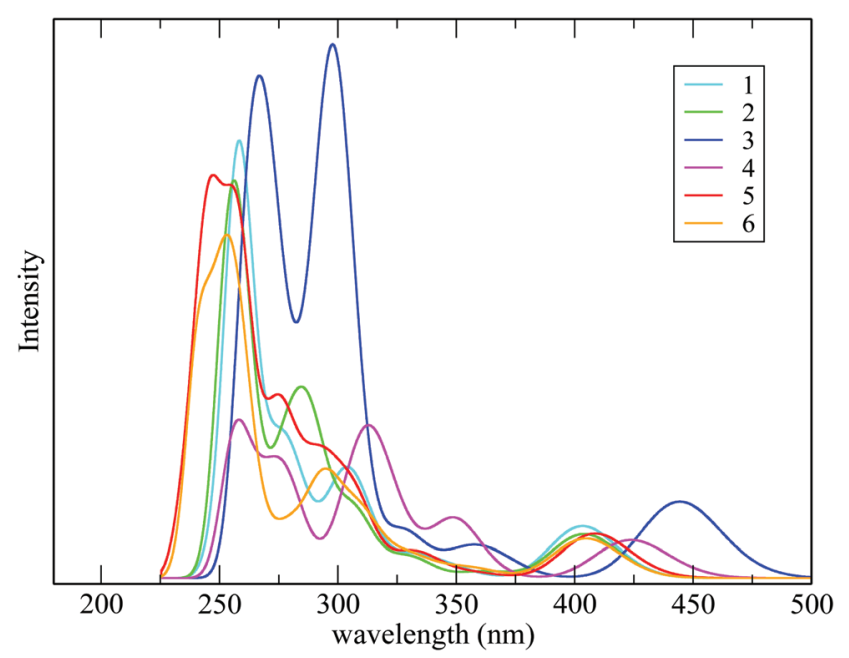

Fig. 6 Computed TDDFT/SRSC absorption spectra for the complexes $1-6$. 
Table 5 Summary of the wavelengths of the predicted absorption bands $\left(\lambda_{\text {abs. }}\right)$ from the TDDFT calculations and wavelengths of emission $\left(\lambda_{\mathrm{em}}\right)$

\begin{tabular}{|c|c|c|c|c|}
\hline \multirow[b]{2}{*}{ Complex } & \multirow[b]{2}{*}{$\lambda_{\text {abs. }}(\mathrm{nm})$} & \multicolumn{3}{|c|}{$\lambda_{\mathrm{em}}(\mathrm{nm})$} \\
\hline & & TDDFT & $\begin{array}{l}\text { TDDFT/ } \\
\text { TDA }\end{array}$ & $\begin{array}{l}\Delta \text { Kohn- } \\
\text { Sham }\end{array}$ \\
\hline 1 & $258,275 \mathrm{sh}, 304,403$ & 588 & 559 & 552 \\
\hline 2 & $256,284,306 \mathrm{sh}, 332 \mathrm{sh}, 404$ & 577 & 550 & 554 \\
\hline 3 & $267,298,329$ sh, 359 sh, 445 & 595 & 577 & 537 \\
\hline 4 & $258,274,313,349,424$ & 548 & 537 & 516 \\
\hline 5 & $250,293,275 \mathrm{sh}, 408$ & 587 & 559 & 545 \\
\hline 6 & $253,295,405$ & 587 & 558 & 547 \\
\hline
\end{tabular}

This transition has a similar character to the feature at about $400 \mathrm{~nm}$ in the absorption spectra. The predicted TDDFT transition energies are consistently higher in energy than the values observed in the experiment, while TDDFT in combination with the TDA gives energies closer to the experiment. This error is associated with the triplet instability in TDDFT and is consistent with recent work ${ }^{32}$ demonstrating that the TDA significantly improves the calculated transition energies for this type of transition. The problems associated with triplet instability are avoided in a $\Delta$ Kohn-Sham approach, and the transition energies predicted with this method are in reasonable agreement with the TDDFT/TDA values and the closest to the experiment. Focusing on the $\Delta$ Kohn-Sham results, the predicted emission wavelengths are similar for complexes 1, 2, 5 and $\mathbf{6}$ with a lower wavelength predicted for complex $\mathbf{4}$. This is consistent with the shift in the emission band observed in the experimental measurements. Comparison of the structures suggests that this change is a consequence of coordination to the benzoquinoline ligand compared to phenylpyridine. The orbitals associated with this ligand are involved in the relevant orbitals for the transition, and it is interesting to note that this change in ligands has a greater effect on the emission than changing $\mathrm{Cl}$ to $\mathrm{Br}$. For complex 3 there is a slight inconsistency with the experiment, where the calculations predict a change in the emission energy compared to 1, 2, 5 and $\mathbf{6}$. While the structure of $\mathbf{3}$ is different from the other complexes, and hence a change in emission energy might be expected, there is no evidence for this in the experimental measurements.

\section{Electroluminescence properties}

Encouraged by the results of photoluminescence (PL) displayed by compounds 1-6 we studied the electroluminescence (EL) properties of these complexes. For this purpose multilayer doped OLED devices A-F with the structure ITO/PEDOT:PSS (30 nm)/PVK:complex (10 wt\%, $50 \mathrm{~nm}) / \mathrm{BATH}(15 \mathrm{~nm}) / \mathrm{AlQ}_{3}$ $(25 \mathrm{~nm}) / \mathrm{Yb}(150 \mathrm{~nm})$ were fabricated. The OLEDs exhibited green emission with similar CIE coordinates for devices A-C, E and $\mathbf{F}$, while coordinates for $\mathbf{D}$ are slightly different (Fig. S23 $\dagger$ ). With the exception of $\mathbf{4}$, which revealed broad-band emission with the maxima at $503 \mathrm{~nm}$, the EL spectra of the complexes consist of two overlapped but rather defined peaks (Fig. 7),

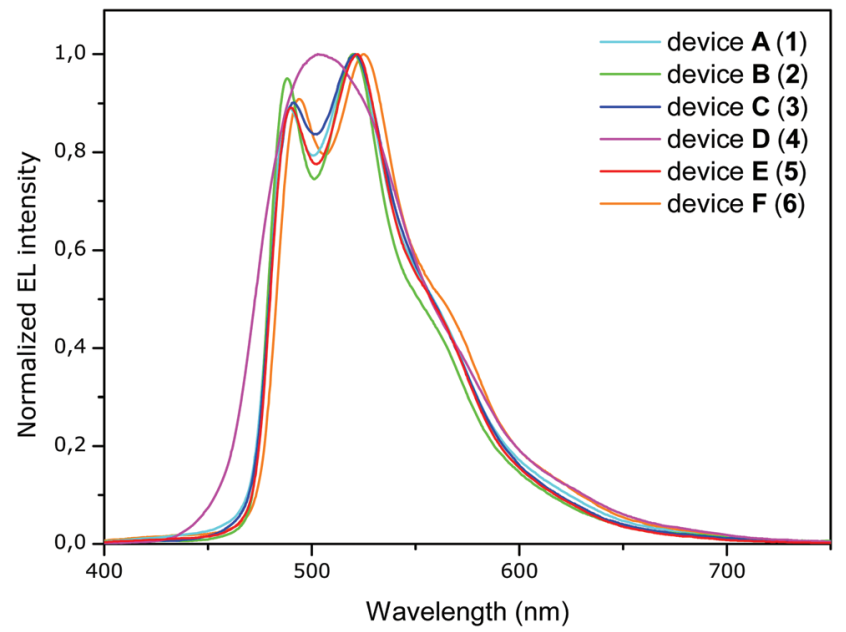

Fig. 7 Electroluminescence of the A-F devices.

which are red-shifted by $5-10 \mathrm{~nm}$ relative to PL of the corresponding compounds. Obviously, the EL of all compounds can be attributed to emission from the mixed ${ }^{3} \mathrm{IL} /{ }^{3} \mathrm{MLCT}$ excited state. It should be noted that undesirable luminescence originating from the PVK host as well as from $\mathrm{AlQ}_{3}$ was not detected. The absence of the PVK band at $440 \mathrm{~nm}$ is reasonable evidence of good quantum confinement and successful energy transfer from ${ }^{3} \mathrm{~T}_{1 \mathrm{p}}$ and ${ }^{3} \mathrm{~T}_{1 \mathrm{f}}$ excited states of $\mathrm{PVK}^{33}$ to the mixed ${ }^{3} \mathrm{IL} /{ }^{3} \mathrm{MLCT}$ state of the platinum(II) complex in the studied host-guest system. It should be noted however that the efficiency of the devices based on triplet host materials such as PVK and CBP can dramatically decrease with increasing applied electrical field due to triplet-triplet (T-T) annihilation in the matrix. ${ }^{34,35}$

The turn-on voltages for the devices were in the range of 6-6.5 V. The maximum brightness of $1896 \mathrm{~cd} \mathrm{~m}^{-2}$ was achieved at $20 \mathrm{~V}$ for the device $\mathbf{B}$ comprising 2 as the luminescent dopant. Moreover, for this complex the highest values of efficiencies among the full series of synthesized compounds were obtained: $\eta_{\mathrm{c} \max }=3.18 \mathrm{~cd} \mathrm{\textrm {A } ^ { - 1 }}, \eta_{\mathrm{p} \text { max }}=0.9 \mathrm{~lm} \mathrm{~W}^{-1}$ and $\mathrm{EQE}_{\max }=3.2 \%$. Current-luminance-voltage characteristics and performance data for the fabricated OLEDs are shown in Fig. 8 and in Table 6,

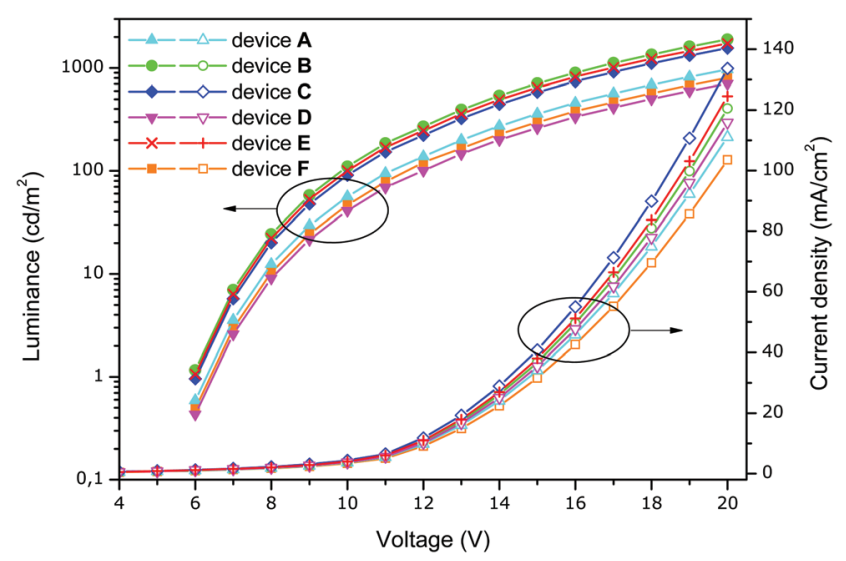

Fig. 8 Current-luminance-voltage relationship for the A-F devices. 
Table 6 Performance data for devices A-F

\begin{tabular}{|c|c|c|c|c|c|c|c|}
\hline Device & $V_{0}{ }^{a}(\mathrm{~V})$ & $\lambda_{\max }(\mathrm{nm})$ & $L_{\max }^{b}\left(\mathrm{~cd} \mathrm{~m}^{-2}\right)$ & $\eta_{\mathrm{c} \max }{ }^{c}\left(\mathrm{~cd} \mathrm{~A}^{-1}\right)$ & $\eta_{\mathrm{p} \max }{ }^{d}\left(\operatorname{lm~W^{-1})}\right.$ & $\mathrm{EQE}_{\max }{ }^{e}(\%)$ & $\operatorname{CIE} 1931^{f}(x, y)$ \\
\hline A & 6.5 & 489,521 & 963 & 1.75 & 0.5 & 2.1 & $0.219,0.664$ \\
\hline B & 6 & 488,520 & 1896 & 3.18 & 0.9 & 3.2 & $0.202,0.686$ \\
\hline D & 6.5 & 503 & 705 & 1.23 & 0.35 & 1.6 & $0.223,0.578$ \\
\hline $\mathbf{E}$ & 6 & 490,522 & 1729 & 2.81 & 0.8 & 3.0 & $0.208,0.685$ \\
\hline $\mathbf{F}$ & 6.5 & 494,525 & 802 & 1.56 & 0.44 & 1.8 & $0.236,0.676$ \\
\hline
\end{tabular}

${ }^{a}$ Turn-on voltage (at $1 \mathrm{~cd} \mathrm{~m}^{-2}$ ). ${ }^{b}$ Maximum luminance (at $20 \mathrm{~V}$ ). ${ }^{c}$ Maximum current efficiency. ${ }^{d}$ Maximum power efficiency. ${ }^{e}$ Maximum external quantum efficiency. ${ }^{f} \mathrm{CIE}$ chromaticity coordinates.

respectively. Their current and power efficiency are shown in Fig. S24 and S25. $\dagger$

It is well known that the EL device efficiency depends considerably on the method of fabrication and the device structure. In order to estimate the performances of the prepared devices a comparison with the other solution-processed OLEDs based on the PVK:Pt(II)-complex emissive layer has been done. In the vast majority of publications it was demonstrated that cyclometalated Pt(II) compounds incorporated into the PVK matrix reveal poor to moderate EL characteristics. ${ }^{36-40}$ The best results, which are similar to those presented above, were achieved for the series of $\mathrm{Pt}$ (II) complexes bearing tridentate 3 -[6'-(naphthalene-2"-yl)pyridine-2'-yl] isoquinoline ligands with fluorine substituents reported by Yuen et al. ${ }^{41}$ We believe that efficiencies of the studied OLEDs can be improved by optimization of the concentration of the luminescent complex and development of more appropriate host-guest system. This study is now in progress.

\section{Conclusion}

A series of $\mathrm{N}$-heterocyclic carbene $\mathrm{Pt}$ (II) complexes based on cyclometallated phenylpyridine and benzoquinoline ligands have been synthesized and structurally characterized in the solid state and in solution to show a typical square planar geometry with the NHC ligand in the trans position with respect to the nitrogen atom of the cyclometallated ligand. The complexes display moderate to strong phosphorescence in solution and in the solid state, which is related to the metal center modulated intraligand $\pi-\pi^{*}$ transitions located at the aromatic system of the cyclometallated ligands with some contribution of the MLCT excited state. This conclusion is strongly supported by the difference in photophysical data found for the phenylpyridine and benzoquinoline complexes and the essentially identical characteristics revealed for the phenylpyridine compounds, in spite of substantial variations in the composition of the lateral ligand environment. The correlation between the Pt-C(cyclometallated) bond length and emission Q.Y./excited state lifetime for the phenylpyridine complexes also indicates primary contribution of the $\pi-\pi^{*}$ excited state localized onto cyclometallated ligands in the emission observed. These observations point to the possible ways of Q.Y. augmentation through the variation in the composition of the ligand sphere, which could give rise to a stronger ligand field effect in the Pt-C bonding. The nature of emission observed was also studied using the DFT and TDDFT approaches which confirmed the assignment mentioned above. The compounds obtained were also used to prepare OLED devices, which display good luminance efficiency emitting in the green area of the visible spectrum.

\section{Acknowledgements}

The authors appreciate financial support from the St Petersburg State University research grant 0.37.169.2014, and RFBR grant 13-03-12411. The NMR, photophysical, analytical and crystallographic measurements were performed using core facilities of St Petersburg State University Research Park: Center for Magnetic Resonance, Center for Optical and Laser Materials Research, Center Chemical Analysis and Materials Research and the X-ray Diffraction Centre, respectively. The computations were performed using the High Performance Computing (HPC) facility at the University of Nottingham. EB acknowledges an ERC Consolidator grant for financial support.

\section{References}

1 J. A. G. Williams, S. Develay, D. L. Rochester and L. Murphy, Coord. Chem. Rev., 2008, 252, 2596-2611.

2 A. K.-W. Chan, E. S.-H. Lam, A. Y.-Y. Tam, D. P.-K. Tsang, W. H. Lam, M.-Y. Chan, W.-T. Wong and W.-W. Yam, Chem. - Eur. J., 2013, 19, 13910-13924.

3 C. Li, S. Wang, Y. Huang, B. Zheng, Z. Tian, Y. Wen and F. Li, Dalton Trans., 2013, 42, 4059-4067.

4 A. Bossi, A. F. Rausch, M. J. Leitl, R. Czerwieniec, M. T. Whited, P. I. Djurovich, H. Yersin and M. E. Thompson, Inorg. Chem., 2013, 52, 12403-12415.

5 S. K. Yen, D. J. Young, H. V. Huynh, L. L. Koh and T. S. A. Hor, Chem. Commun., 2009, 6831-6833.

6 J. J. Hu, S.-Q. Bai, H. H. Yeh, D. J. Young, Y. Chi and T. S. A. Hor, Dalton Trans., 2011, 40, 4402-4406. 
7 K. Li, Y. Chen, W. Lu, N. Zhu and C.-M. Che, Chem. - Eur. J., 2011, 17, 4109-4112.

8 H. Uesugi, T. Tsukuda, K. Takao and T. Tsubomura, Dalton Trans., 2013, 42, 7396-7403.

9 X. Yang, C. Yao and G. Zhou, Platinum Met. Rev., 2013, 57, 2-16.

10 C.-M. Che, M. Yang, K.-H. Wong, H.-L. Chan and W. Lam, Chem. - Eur. J., 1999, 5, 3350-3356.

11 D.-L. Ma, T. Y.-T. Shum, F. Zhang, C.-M. Che and M. Yang, Chem. Commun., 2005, 4675-4677.

12 T. Zou, C.-N. Lok, Y. M. E. Fung and C.-M. Che, Chem. Commun., 2013, 49, 5423-5425.

13 J. R. Kumpfer, S. D. Taylor, W. B. Connick and S. J. Rowan, J. Mater. Chem., 2012, 22, 14196-14204.

14 N. Godbert, T. Pugliese, I. Aiello, A. Bellusci, A. Crispini and M. Ghedini, Eur. J. Inorg. Chem., 2007, 5105-5111.

15 S. Patil, J. Claffey, A. Deally, M. Hogan, B. Gleeson, L. M. Menéndez Méndez, H. Müller-Bunz, F. Paradisi and M. Tacke, Eur. J. Inorg. Chem., 2010, 2010, 1020-1031.

16 J. A. V. Er, A. G. Tennyson, J. W. Kamplain, V. M. Lynch and C. W. Bielawski, Eur. J. Inorg. Chem., 2009, 2009, 17291738.

17 I. E. Crandall, W. A. Szarek and J. Z. Vlahakis, US Pat., 20110257235 A1, 2011.

18 V. Gandin, M. Pellei, M. Marinelli, C. Marzano, A. Dolmella, M. Giorgetti and C. Santini, J. Inorg. Biochem., 2013, 129, 135-144.

19 K. Rurack and M. Spieles, Anal. Chem., 2011, 83, 12321242.

20 A. D. Becke, J. Chem. Phys., 1993, 98, 5648-5652.

21 S. Grimme, J. Antony, T. Schwabe and C. Mück-Lichtenfeld, Org. Biomol. Chem., 2007, 5, 741-758.

22 M. Kaupp, P. v. R. Schleyer, H. Stoll and H. Preuss, J. Chem. Phys., 1991, 94, 1360-1366.

23 A. Bergner, M. Dolg, W. Küchle, H. Stoll and H. Preuß, Mol. Phys., 1993, 80, 1431-1441.

24 S. Hirata and M. Head-Gordon, Chem. Phys. Lett., 1999, 314, 291-299.

25 Y. Shao, L. F. Molnar, Y. Jung, J. Kussmann, C. Ochsenfeld, S. T. Brown, A. T. B. Gilbert, L. V. Slipchenko, S. V. Levchenko, D. P. O’Neill, R. A. D. Jr., R. C. Lochan, T. Wang, G. J. O. Beran, N. A. Besley, J. M. Herbert, C. Y. Lin, T. V. Voorhis, S. H. Chien, A. Sodt, R. P. Steele, V. A. Rassolov, P. E. Maslen, P. P. Korambath, R. D. Adamson, B. Austin, J. Baker, E. F. C. Byrd, H. Dachsel, R. J. Doerksen, A. Dreuw, B. D. Dunietz, A. D. Dutoi, T. R. Furlani, S. R. Gwaltney, A. Heyden,
S. Hirata, C.-P. Hsu, G. Kedziora, R. Z. Khalliulin, P. Klunzinger, A. M. Lee, M. S. Lee, W. Liang, I. Lotan, N. Nair, B. Peters, E. I. Proynov, P. A. Pieniazek, Y. M. Rhee, J. Ritchie, E. Rosta, C. D. Sherrill, A. C. Simmonett, J. E. Subotnik, H. L. W. Iii, W. Zhang, A. T. Bell, A. K. Chakraborty, D. M. Chipman, F. J. Keil, A. Warshel, W. J. Hehre, H. F. S. Iii, J. Kong, A. I. Krylov, P. M. W. Gill and M. Head-Gordon, Phys. Chem. Chem. Phys., 2006, 8, 3172-3191.

26 G. M. Sheldrick, Acta Crystallogr., Sect. A: Fundam. Crystallogr., 2008, 64, 112-122.

27 O. V. Dolomanov, L. J. Bourhis, R. J. Gildea, J. A. K. Howard and H. Puschmann, J. Appl. Crystallogr., 2009, 42, 339-341.

28 G. M. Sheldrick, SADABS, Univ. Gottingen, Germany, 2004.

29 CrysAlisPro, Version 1.171.36.20 (release 27-06-2012), Agilent Technologies.

30 J. Brooks, Y. Babayan, S. Lamansky, P. I. Djurovich, I. Tsyba, R. Bau and M. E. Thompson, Inorg. Chem., 2002, 41, 3055-3066.

31 J. A. G. Williams, A. Beeby, E. S. Davies, J. A. Weinstein and C. Wilson, Inorg. Chem., 2003, 42, 8609-8611.

32 M. J. G. Peach, N. Warner and D. J. Tozer, Mol. Phys., 2013, 111, 1271-1274.

33 T. Ye, J. Chen and D. Ma, Phys. Chem. Chem. Phys., 2010, 12, 15410-15413.

34 C. Adachi, M. A. Baldo and S. R. Forrest, J. Appl. Phys., 2000, 87, 8049-8055.

35 S. Lamansky, R. C. Kwong, M. Nugent1, P. I. Djurovich and M. E. Thompson, Org. Electron., 2001, 2, 53-62.

36 C.-L. Lee, K. B. Lee and J.-J. Kim, Mater. Sci. Eng., B, 2001, 85, 228-231.

37 Q. Liu, L. Thorne, I. Kozin, D. Song, C. Seward, M. D’Iorio, Y. Tao and S. Wang, J. Chem. Soc., Dalton Trans., 2002, 3234-3240.

38 W. Zhuang, Y. Zhang, Q. Hou, L. Wang and Y. Cao, J. Polym. Sci., Part A: Polym. Chem., 2006, 44, 4174-4186.

39 C. W. Lee, C. Renaud, P. Le Rendu, T. P. Nguyen, B. Seneclauze, R. Ziessel, H. Kanaan and P. Jolinat, Solid State Sci., 2010, 12, 1873-1876.

40 C. O. Paul-Roth, S. Drouet, A. Merhi, J. A. G. Williams, L. F. Gildea, C. Pearson and M. C. Petty, Tetrahedron, 2013, 69, 9625-9632.

41 M.-Y. Yuen, S. C. F. Kui, K.-H. Low, C.-C. Kwok, S. S.-Y. Chui, C.-W. Ma, N. Zhu and C.-M. Che, Chem. - Eur. J., 2010, 16, 14131-14141. 